\title{
Forms of Bullying and Associations Between School Perceptions and Being Bullied Among Finnish Secondary School Students Aged 13 and 15
}

\author{
Ilona Markkanen ${ }^{1}$ (D) Raili Välimaa ${ }^{2}$ - Lasse Kannas ${ }^{3}$ \\ Published online: 6 December 2019 \\ (C) The Author(s) 2019
}

\begin{abstract}
The study aimed to examine the extent to which Finnish secondary school students experience bullying, how they are bullied, and whether being bullied is associated with school perceptions. The analyses were based on data from the Finnish part of the international Health Behaviour in School-aged Children (HBSC) study, and were obtained from 4262 students aged 13 and 15. The sample was nationally representative. Logistic regression analysis was performed to identify the associations between school perceptions and being bullied. Younger students reported being bullied more often than older students. Among younger students, boys were more often bullied than girls of the same age. There was no significant difference between the genders among the older students. The most common form of being bullied was verbal teasing. Boys tended to be bullied in physical ways, while girls were bullied in more indirect ways. Students with low levels of school engagement, students with poor relations with peers, and students who reported better teacher-student relations were more likely to be bullied. Feelings of loneliness and lower family affluence were also associated with being bullied. Improving the perceptions of school, and of the school experience as a whole, might have an effect on bullying at school.
\end{abstract}

Keywords Bullying $\cdot$ School perceptions $\cdot$ Forms of bullying $\cdot$ Secondary school

Background Bullying is a global phenomenon. In an analysis covering 40 countries, over one-quarter of participating students were found to be involved in bullying in some manner (Craig et al. 2009). International comparisons of bullying indicate that in Finland, as in other Scandinavian countries, the prevalence in bullying is relatively low (Craig et al. 2009; Currie et al. 2012; Due et al. 2008), with rates of bullying

Ilona Markkanen

Ilona.markkanen@jyu.fi

Raili Välimaa

raili.valimaa@jyu.fi

Lasse Kannas

lasse.kannas@jyu.fi

1 Finnish Institute for Educational Research, University of Jyväskylä, Jyväskylä, Finland

2 Faculty of Sports and Health Sciences, Research Center for Health Promotion, University of Jyväskylä, Jyväskylä, Finland

3 Faculty of Sports and Health Sciences, Research Center for Health, University of Jyväskylä, Jyväskylä, Finland having decreased since the turn of the millennium (Chester et al. 2015; Molcho et al. 2009; UNESCO 2019). Despite this, studies have shown that 6-15\% of Finnish students are bullied regularly at school, with boys being bullied more often than girls (Craig et al. 2009; Luopa et al. 2014; Arnarsson et al. 2019). Victimisation appears to decrease with age (Craig et al. 2009; Luopa et al. 2014; Arnarsson et al. 2019). Also, lower family affluence has been associated with victimisation (see e.g. Tippett and Wolke 2014).

Students, teachers, and researchers can have different conceptualisations of bullying, making it important to define bullying precisely. The most commonly used definition of bullying is that of Olweus (1993), who defines bullying as deliberate and repeated long-term exposure to negative acts, performed by a person or group of persons perceived as having higher status or greater strength than the victim. Bullying can involve verbal acts, such as threats, insults, or use of nicknames, or it can encompass physical acts such as assault or theft. In addition, social acts such as exclusion from the peer group are considered to manifest bullying. Bullying does not involve merely those who are victims and/or bullies, since bystanders, too, have a role (Hamarus 2006; Salmivalli 
2010). Bullying also has a tendency to develop new forms over time. In recent years, attention has been drawn to cyberbullying, i.e. bullying via ICT. It can be difficult for schools to intervene in such forms of bullying, since the bullying may well spread into free-time environments (Hong and Espelage 2012).

The school should be a safe place for every student, given that it should be a place where students go to learn, and not to be afraid. At school, bullying aggravates feelings of insecurity, and it threatens students' health, well-being, and motivation towards school work (Pörhölä 2008). In several studies, bullying in general has been associated with poor health (Callaghan et al. 2014; UNESCO 2019), health complaints (Due et al. 2005; Nansel et al. 2004; Pörhölä 2008; Hager and Leadbeater 2015), poor self-esteem (Gendron et al. 2011), poorer grades (Erginoz et al. 2015; Juvonen et al. 2010; UNESCO 2019), psychological distress (Sanders 2019), depressive symptoms (Minkkinen 2015), and loneliness (Hong and Espelage 2012; Acquah et al. 2016; UNESCO 2019). In research, loneliness has been recognised as one factor associated with adverse peer relations and an important predictor of peer victimisation (see e.g. Acquah et al. 2016: Pavri 2015). In addition to the observed shortterm effects, studies have implied that bullying has longterm effects on the lives of students who have been bullied regularly (Hong and Espelage 2012; Zych et al. 2015).

Students' perceptions of school are known to be associated with students' well-being (Minkkinen 2015), health behaviour (Haapasalo et al. 2012), and academic achievement (Freeman et al. 2009; Haapasalo et al. 2010). A number of studies have implied that negative perceptions of school, or a poor school climate, are associated with being bullied (Erginoz et al. 2015; Glew et al. 2008; Turner et al. 2014). A study by Harel-Fisch et al. (2011) indicated that negative perceptions of the school, and especially connectedness to the school, are strongly associated with bullying. Yang et al. (2018) argued that the experience of being bullied has a negative effect on students' school engagement, and that the impact is actually more negative in schools with a more positive school climate than in schools with a less positive climate.

The present study aimed, first of all, to examine the extent to which Finnish secondary school students experience bullying and different forms of bullying at school. The second aim was to investigate the associations between experiences of victimisation, school perceptions, and students' individual characteristics, including age, gender, educational aspiration, perceived family affluence, and feelings of loneliness.

\section{Methods}

\section{Data}

The data presented here were obtained from the Finnish part of the Health Behaviour in School-aged Children (HBSC)
2010 study. The data were collected through school-based surveys, utilising anonymous, voluntary, and standardised questionnaires based on the international protocol of the HBSC Study. The source language for the original HBSC questionnaire was English. In order to follow the research protocol, and to ensure correctness in the interpretations, each participating country had to first translate the questionnaire from English into the national language, and then retranslate it back into English by an independent professional translator (:dito_existswww.hbsc.org; Currie et al. 2008; Roberts et al. 2009).

\section{Participants}

The participants, i.e. young people aged 11,13 , and 15 , were selected using cluster sampling, and the samples were nationally representative (Currie et al. 2008; Roberts et al. 2009; :dito_existswww.hbsc.org). The present study used the responses provided by Finnish students aged 13 and 15 . There were in total 4262 respondents of which 2152 were 13 years old (1045 boys, 1107 girls) and 2110 were 15 years old (1008 boys, 1102 girls). The overall response rate was $70 \%$.

\section{Measures}

Bullying victimisation was measured with a single question: How often have you been bullied at school in the past couple of months? In the introduction to the question, bullying was defined according to the definition by Olweus (1993):

We say a student is being bullied when another student, or a group of students, say or do nasty and unpleasant things to him or her. It is also bullying when a student is teased repeatedly in a way he or she does not like or when he or she is deliberately left out of things. But it is not bullying when two students of about the same strength or power argue or fight. It is also not bullying when a student is teased in a friendly and playful way.

The different forms of bullying were measured by seven items: I was called mean names, was made fun of, or teased in a hurtful way; Other students left me out of things on purpose, excluded me from their group of friends, or completely ignored me; I was hit, kicked, pushed, shoved around, or locked indoors; Other students told lies or spread false rumours about me and tried to make others dislike me; Other students made sexual jokes, or gestures to me; I've been bullied on the Internet, by e-mail, or with pictures; and I've been bullied via mobile phone.

The response options for all items above were the following: never, only once or twice, two or three times a month, about once a week, and several times a week. 
The students' school perceptions were measured by a set of questions concerning the school atmosphere, the school environment, teachers, peers, and parents. The questions were based on previous HBSC research findings, which highlight the importance of the psychosocial school environment for students' health and health behaviour. There were 37 statements in total (Table 1). The students gave their opinion by expressing the degree to which they agreed with the statements, using a scale with five response options: strongly agree, agree, neither/nor, disagree, and strongly disagree.

Explorative factor analysis (with Oblimin rotation) was conducted for the 37 variables in order to reduce the data, and to uncover the underlying dimensions of the school perceptions. The factor analysis resulted in seven factors (Table 1). The items in each factor were added up to give sum scores, which were named as follows: School engagement (3 items), which indicated the outlook on school life and on belonging at school. Liking school (4 items) indicated a positive outlook towards school and schoolwork. Parental support (5 items) indicated the parents' involvement in schoolwork. Student relations (5 items) reflected relationships and interactions at school. Academic support (8 items) and Teacher-student relations (9 items) reflected the student-teacher relations at school, and School strain (3 items) reflected the workload and attitudes towards school. To preserve the original scale for the sum scores formed, the sum scores were divided by the number of items in each sum score. The internal consistencies of the sum scores were satisfactory. Cronbach's alpha for the sum scores varied between 0.76 and 0.87 .

Educational aspiration was measured by a single item: What do you think you will do when you finish comprehensive school? Here, students were asked if they were intending to apply for general upper secondary education, or for vocational education, or for an apprenticeship; also if they were intending to get a job, or intending to remain unemployed, or if they were as yet undecided. The variable was rescaled so that the statements I'm going to apply for general upper secondary school and I'm going to apply for vocational school were kept as they were, and the others were omitted from the analysis $(n=401)$.

Perceived family affluence was measured with a single question, How well off do you think your family is? The item had five response options: very well off, quite well off, average, not so well off, and not at all well off. For the analysis, two categories were formed, comprising the first two options, very well off and well off, and the last two options, not so well off and not at all well off.

Feeling of loneliness was also measured with a single question in which the students were asked if they ever felt lonely. The question had four response options Yes, very often; Yes, quite often; Yes, sometimes; and No. The variable was dichotomised into those who felt lonely, and those who did not.
In addition to the measures above, we used demographic variables such as age and gender.

\section{Statistical Analysis}

Binary logistic regression analysis was conducted to analyse the associations between school perceptions and victimisation of bullying. For the purposes of the analysis, the school perception variables were rescaled. School engagement was divided into three categories: high, average, and low engagement. All the other sum scores were split into two categories according to the original scale, hence placed on the positive or negative side. The responses regarding victimisation were also dichotomised into those who had been bullied and to those who had not.

\section{Results}

Most of the students reported that they had never been bullied during the past few months. Nevertheless, almost one in ten reported that they had been bullied frequently at school. When the results were analysed by age and gender, it emerged that boys aged 13 were bullied more often than girls of the same age $(p=0.044)$ (Table 2). There was no significant gender difference among 15-year-olds (Table 3). Younger students reported victimisation more often than older students; about $6 \%$ of the 13 -year-olds and about $4 \%$ of the 15 -year-olds had been bullied weekly at school $(p<0.001)$.

The most common form of being bullied was verbal teasing. Almost every third student reported that they had been called mean names, teased, or made fun of at least once or twice a month. The results clearly indicated gender-specific forms of bullying. Hence, boys tended to be victimised in more physical ways, i.e. by being hit, kicked, or pushed, while girls were bullied in more indirect ways; i.e. they were excluded from the group, or false rumours were spread to try to make others dislike the victim. Among 13-year-old boys, $16 \%$ reported being hit, kicked, pushed, shoved around, or being locked indoors at least once or twice a month, whereas among 13 -year-old girls, $7 \%$ reported this kind of bullying $(p<0.001)$. Such physical forms of bullying at least once or twice a month were experienced by $14 \%$ of the boys aged 15 , and by $4 \%$ of the girls aged $15(p<0.001)$. Among the girls, $22 \%$ of the younger girls and $19 \%$ of the older girls reported the experience of others leaving them out of things on purpose, of exclusion from a group of friends, or of being totally ignored at least once or twice a month. Similar phenomena were reported by $17 \%$ of the younger boys, and by $14 \%$ of the older boys (13-year-olds, $p=0.011$; 15-year-olds, $p<0.001$ ). Among younger students, more girls than boys reported victimisation by students who told lies about them, spread false rumours about them, or made others dislike them (girls 
Table 1 Results from factor analysis: seven factors describing school perceptions, $n=4262$

Factors

Communalities

1. 2. $\quad$ 3. $\quad$ 4. $\quad$ 5. $\quad 6.4$.

1. School engagement

I feel I belong at this school

0.679

0.567

I feel safe at this school

0.608

0.467

Our school is a nice place to be

0.585

0.636

2. Liking school

I like being in school

I look forward to going to school

I enjoy school activities

I wish I did not have to go to school (reversed)

3. Parental support

My parents are interested in what happens to me at school

My parents encourage me to do well at school

If I have a problem at school, my parents are ready to help

My parents are willing to help me with my homework

My parents are willing to come to school to talk to teachers

4. Student relations

The students in my class treat each other with respect

Most of the students in my class(es) are kind and helpful

The students in my class(es) enjoy being together

Other students accept me as I am

When one of my costudents is feeling down, one of us tries to help

$-0.817$

0.703

$-0.787$

0.682

$-0.506$

0.501

$-0.452$

0.410

$-0.807$

0.535

$-0.802$

0.545

$-0.797$

0.559

$-0.699$

0.451

$-0.577$

0.392

. Academic support

My teachers tell me how to do better on school-tasks

In feel that my teachers provide me with choices and options

My teachers try to understand how I think before suggesting a new way to do things

My teachers make sure that I really understand my goals and what I need to do

My teachers listen to how I would like to do things

My teachers guide me how to solve tasks

My teachers encourage me when I do school work

When I need extra help, I can get it
0.753
0.726
0.704
0.644
0.520

0.493

0.453

0.402

0.404

0.355

$-0.705$

0.400

$-0.695$

0.457

$-0.636$

0.507

$-0.610$

0.458

$-0.608$

0.490

$-0.522$

0.399

$-0.518$

0.412

$-0.497$

0.409

6. Teacher-student relations

I feel my teachers care about me as a person

I feel a lot of trust in my teachers

Most of my teachers are friendly

I feel that my teachers accept me just as I am

Our teachers treat us fairly

My teachers are interested in knowing how I'm doing

I am encouraged to express my own views in my class(es)

The students are not treated too severely/strictly in this school

The rules in this school are fair

7. School strain

I have too much school work

0.559

0.683

0.569

0.669

0.569

0.618

0.499

00.614

0.527

0.585

0.519

0.526

0.479

0.424

0.428

0.354

0.403

0.331

0.426

I find school tiring

$0.763 \quad 0.432$

$\begin{array}{ll}0.647 & 0.479\end{array}$

I find school difficult

0.5490 .361

Cronbach's alpha

$\begin{array}{lllll}0.832 & 0.854 & 0.853 & 0.812 & 0.868\end{array}$

$0.882 \quad 0.760$ 
Table 2 Different forms of bullying: percentages of 13-year-old students who have experienced different forms of bullying, by gender

\begin{tabular}{|c|c|c|c|c|c|c|c|c|c|}
\hline & \multicolumn{9}{|c|}{13 years } \\
\hline & \multicolumn{4}{|l|}{ Boys } & \multicolumn{4}{|l|}{ Girls } & \multirow[t]{2}{*}{ Sig. } \\
\hline & $\begin{array}{l}\text { Never, } \\
\%\end{array}$ & $\begin{array}{l}\text { Once or } \\
\text { twice a } \\
\text { month, \% }\end{array}$ & $\begin{array}{l}2-3 \text { times } \\
\text { a month, } \\
\%\end{array}$ & $\begin{array}{l}\text { Weekly, } \\
\%\end{array}$ & $\begin{array}{l}\text { Never, } \\
\%\end{array}$ & $\begin{array}{l}\text { Once or } \\
\text { twice a } \\
\text { month, \% }\end{array}$ & $\begin{array}{l}2-3 \text { times } \\
\text { a month, } \\
\%\end{array}$ & $\begin{array}{l}\text { Weekly, } \\
\%\end{array}$ & \\
\hline Incidences of bullying (overall) & 65 & 22 & 6 & 7 & 70 & 18 & 6 & 6 & 0.044 \\
\hline $\begin{array}{l}\text { I was called mean names, was made fun of, or } \\
\text { teased in a hurtful way }\end{array}$ & 62 & 24 & 6 & 8 & 65 & 21 & 6 & 8 & 0.457 \\
\hline $\begin{array}{l}\text { Other students left me out of things on purpose, } \\
\text { excluded me from their group of friends, or } \\
\text { completely ignored me }\end{array}$ & 83 & 10 & 4 & 3 & 78 & 13 & 4 & 5 & 0.011 \\
\hline $\begin{array}{l}\text { I was hit, kicked, pushed, shoved around, or locked } \\
\text { indoors }\end{array}$ & 83 & 10 & 3 & 3 & 93 & 4 & 1 & 2 & $<0.001$ \\
\hline $\begin{array}{l}\text { Other students told lies or spread false rumours } \\
\text { about me and tried to make others dislike me }\end{array}$ & 76 & 15 & 4 & 5 & 72 & 20 & 4 & 4 & 0.026 \\
\hline Other students made sexual jokes, or gestures to me & 86 & 8 & 2 & 4 & 86 & 8 & 2 & 3 & 0.971 \\
\hline $\begin{array}{l}\text { I've been bullied on the Internet, by e-mail, or with } \\
\text { pictures }\end{array}$ & 93 & 4 & 2 & 2 & 91 & 6 & 1 & 1 & 0.039 \\
\hline I've been bullied via mobile phone & 94 & 3 & 2 & 1 & 94 & 4 & 1 & 1 & 0.269 \\
\hline
\end{tabular}

$28 \%$, boys $24 \%$; $p=0.026$ ), also victimisation by internet, email, or pictures (girls $9 \%$, boys $7 \% ; p=0.039$ ). Older boys experienced more name calling, mockery, or teasing than girls (boys $36 \%$, girls $28 \%$; $p<0.001$ ). Experiences of multiple forms of bullying in the past couple of months were not very common: most of the students reported having been bullied in one or two different ways, rather than in various (3-7) ways (Table 4).

Some of the school perceptions under study were strongly associated with bullying. Students with low levels of school engagement were more likely to be bullied than their peers with higher engagement (OR 1.62, $p<0.001$ ). Moreover, students with poor student relationships at school were more likely to be victims of bullying behaviour (OR 2.65, $p<0.001)$. Students who perceived their teacher-student relations to be better were more likely to be bullied than their counterparts (OR 1.24, $p=0.046$ ) (Table 5).

Gender and age seemed to be influential predictors of bullying. Younger students were almost twice as likely to have been victimised than older ones (OR 1.98, $p<0.001)$, and

Table 3 Different forms of bullying: percentages of 15-year-old students who have experienced different forms of bullying, by gender

\begin{tabular}{|c|c|c|c|c|c|c|c|c|}
\hline \multicolumn{4}{|l|}{ Boys } & \multicolumn{4}{|l|}{ Girls } & \multirow[t]{2}{*}{ Sig. } \\
\hline $\begin{array}{l}\text { Never, } \\
\%\end{array}$ & $\begin{array}{l}\text { Once or } \\
\text { twice a } \\
\text { month, } \%\end{array}$ & $\begin{array}{l}2-3 \text { times } \\
\text { a month, } \\
\%\end{array}$ & $\begin{array}{l}\text { Weekly, } \\
\%\end{array}$ & $\begin{array}{l}\text { Never, } \\
\%\end{array}$ & $\begin{array}{l}\text { Once or } \\
\text { twice a } \\
\text { month, \% }\end{array}$ & $\begin{array}{l}2-3 \text { times } \\
\text { a month, } \\
\%\end{array}$ & $\begin{array}{l}\text { Weekly, } \\
\%\end{array}$ & \\
\hline 74 & 17 & 4 & 5 & 77 & 15 & 4 & 4 & 0.283 \\
\hline 64 & 23 & 5 & 7 & 72 & 17 & 6 & 5 & $<0.001$ \\
\hline 86 & 9 & 2 & 3 & 81 & 11 & 3 & 6 & 0.001 \\
\hline 86 & 9 & 3 & 3 & 96 & 3 & 1 & 2 & $<0.001$ \\
\hline 81 & 11 & 4 & 3 & 78 & 13 & 6 & 3 & 0.166 \\
\hline 83 & 9 & 3 & 5 & 83 & 10 & 4 & 3 & 0.084 \\
\hline 95 & 3 & 1 & 1 & 94 & 4 & 1 & 1 & 0.886 \\
\hline 97 & 2 & 1 & 1 & 97 & 2 & 1 & 0 & 0.609 \\
\hline
\end{tabular}


Table 4 Multiplicity in forms of bullying: percentages of students who have been bullied in multiple ways, by age and gender

\begin{tabular}{|c|c|c|c|c|c|c|}
\hline & \multicolumn{2}{|l|}{13 years } & \multirow[t]{2}{*}{ Sig. } & \multicolumn{2}{|l|}{15 years } & \multirow[t]{2}{*}{ Sig. } \\
\hline & Boys, \% & Girls, \% & & Boys, \% & Girls, \% & \\
\hline None & 50 & 46 & 0.028 & 54 & 52 & 0.136 \\
\hline 1-2 ways & 32 & 37 & & 30 & 34 & \\
\hline 3-7 ways & 18 & 17 & & 16 & 14 & \\
\hline
\end{tabular}

boys were more likely to have been victimised than girls (OR $1.70, p<0.001)$. Feelings of loneliness were also associated with the experience of victimisation. Those students who felt lonely were more likely to be victimised than those who never felt lonely $(\mathrm{OR}=2.28, p<0.001)$. Having a poor socioeconomic position was also associated with being a victim of bullying. Those students who perceived their family affluence as low were almost twice as likely to be bullied as those who perceived their position to be good (OR 1.91, $p<0.001$ ) (Table 5).

\section{Discussion}

The prevalence of being a victim of bullying and the different forms of bullying were fairly consistent with previous studies. In Finland, about one-tenth of students are bullied regularly in schools, younger students are victimised more often than older students (Analitis et al. 2009; Craig et al. 2009; Wang et al. 2009; UNESCO 2019), and victimised students tend to have lower socioeconomic position (Due et al. 2009; Tippett and Wolke 2014: Due et al. 2019). It is often claimed that boys are bullied more than girls (Due et al. 2005; Erginoz et al. 2015; Craig et al. 2009; Callaghan et al. 2014; UNESCO 2019). However, in the present study, this gender difference was found only among younger students. This study also lends support to findings from previous studies, in which girls were found to be bullied primarily in verbal ways, and boys in physical ways (Wang et al. 2009: Hager and Leadbeater 2015; UNESCO 2019). In planning interventions, gender differences should be taken into account, insofar as boys and girls differ clearly in terms of the forms in which they are victimised, and not merely in the prevalence of victimisation.

The Finnish Basic Education Act and the National Core Curriculum oblige education providers to have 'a plan for safeguarding the pupils against violence, bullying and harassment as a part of the school welfare plan' (Finnish National Board of Education 2016). According to TEAviisari (an online tool to show the direction of health-promoting work in municipalities), 94\% of Finnish comprehensive schools do have a recorded bullying prevention plan, $96 \%$ of schools have a recorded practice for intervening bullying, and $92 \%$ a recorded practice for post-intervention monitoring of bullying (:dito_existswww.teaviisari.fi). Certain national programs have been proven, at least to some degree, to be effective in tackling bullying, as in the case of the KiVa antibullying program (:dito_existswww.kivaprogram.net; Sainio 2014). KiVa antibullying program is a research-based whole school intervention program that stems from the participant role approach. KiVa program has been widely used in Finnish comprehensive schools in the past 10 years. However, these research-based intervention programs require time, effort, and commitment, which affects the sustainability of such programs. Therefore, further research and development is needed to make the programs meet the needs of changing society and resources of the schools (Sainio 2014; Haataja 2016). Nevertheless, no fully comprehensive results have been published on the effectiveness of these plans and programs. Interestingly, a study by Luopa et al. (2014) has indicated that within Finland, students' feelings of safety at school have increased during the past decade, despite the fact that the prevalence of bullying has remained at more or less the same level.

It is also worth mentioning that in Finland, health education is a standalone obligatory subject in schools. Prevention of bullying and related themes play an important role in the aims and the contents of this school subject (Aira et al. 2014). Health education teachers are fairly well prepared to deal with the bullying issues in their classes because the health education teacher education programmes in universities and health education text books used in schools as well as the in-service training courses introduce many important tools to prevent bullying and to promote safetiness at school (Välimaa et al. 2008; Paakkari and Paakkari 2019). The HBSC study has been of great significance in preparing antibullying strategies and health promotion programs for schools. It has also been utilized in health education teacher training and for materials for health education at the university and school level. The HBSC study has also been utilized in preparation of the antibullying strategy as well as health promotion programmes for schools by the Finnish National Board of Education.

In the present study, the percentage of cyberbullying was found to be fairly low (with less than $10 \%$ of respondents having experienced cyberbullying). This is of interest, given the attention the phenomenon has received in the media, and also comparisons with other studies from other countries (see e.g. Patchin and Hinduja 2012). A review by Patchin and Hinduja (2012) revealed that on average almost a fifth of students are victims of cyberbullying. One reason for the low prevalence in our data could be that the students may have found it difficult to answer the questions on cyberbullying. A point to note here is that once pictures (for example) are put online, they remain there forever; thus, the same picture can circulate in multiple apps or sites, and this makes it hard to determine whether one is dealing with a single or a repeated act. One must bear in mind also that most of the questions on 
Table 5 Binary logistic regression analysis: factors associated with being bullied

\begin{tabular}{|c|c|c|c|c|c|}
\hline Items & $n$ & Bullied, \% & OR & Sig. & $95 \%$ confidence interval \\
\hline \multicolumn{6}{|l|}{ Gender } \\
\hline Boys & 1812 & 30 & 1.697 & \multirow[t]{2}{*}{$<0.001$} & \multirow[t]{2}{*}{$1.445-1.992$} \\
\hline Girls & 2044 & 26 & 1.00 & & \\
\hline \multicolumn{6}{|l|}{ Age } \\
\hline 13 & 1871 & 32 & 1.979 & \multirow[t]{2}{*}{$<0.001$} & \multirow[t]{2}{*}{$1.682-2.328$} \\
\hline 15 & 1985 & 24 & 1.00 & & \\
\hline \multicolumn{6}{|c|}{ Perceived family affluence } \\
\hline Good & 2682 & 26 & 1.00 & & \\
\hline Average & 960 & 30 & 1.069 & 0.464 & $0.894-1.279$ \\
\hline Poor & 214 & 48 & 1.913 & $<0.001$ & $1.399-2.615$ \\
\hline \multicolumn{6}{|c|}{ Expectations for further studies } \\
\hline High school & 2111 & 27 & 1.00 & & \\
\hline Vocational school & 1344 & 28 & .931 & 0.431 & $0.779-1.112$ \\
\hline \multicolumn{6}{|c|}{ Academic achievement } \\
\hline Good & 2237 & 27 & 1.021 & \multirow[t]{2}{*}{0.814} & \multirow[t]{2}{*}{$0.861-1.279$} \\
\hline Average or below & 1619 & 29 & 1.00 & & \\
\hline \multicolumn{6}{|l|}{ Feeling of loneliness } \\
\hline Yes & 2135 & 37 & 2.820 & \multirow[t]{2}{*}{$<0.001$} & \multirow[t]{2}{*}{$2.385-3.335$} \\
\hline No & 1721 & 17 & 1.00 & & \\
\hline \multicolumn{6}{|l|}{ School engagement } \\
\hline High & 2802 & 24 & 1.00 & \multirow[b]{2}{*}{$<0.001$} & \multirow[b]{2}{*}{$1.336-1.959$} \\
\hline Low & 1054 & 40 & 1.618 & & \\
\hline \multicolumn{6}{|l|}{ Parental support } \\
\hline Supportive & 3501 & 27 & 1.00 & & \\
\hline Not supportive & 355 & 36 & 1.076 & 0.582 & $0.829-1.397$ \\
\hline \multicolumn{6}{|l|}{ Liking school } \\
\hline Much & 2251 & 25 & 1.097 & \multirow[t]{2}{*}{0.331} & \multirow[t]{2}{*}{$0.910-1.323$} \\
\hline Less & 1605 & 32 & 1.00 & & \\
\hline \multicolumn{6}{|l|}{ Student relations } \\
\hline Good relations & 2934 & 22 & 1.00 & \multirow[b]{2}{*}{$<0.001$} & \multirow[b]{2}{*}{$2.220-3.164$} \\
\hline Poor relations & 922 & 46 & 2.650 & & \\
\hline \multicolumn{6}{|l|}{ Academic support } \\
\hline High & 2528 & 25 & 1.00 & & \\
\hline Low & 1328 & 32 & 1.090 & 0.356 & $0.908-1.309$ \\
\hline \multicolumn{6}{|c|}{ Teacher-student relations } \\
\hline High & 2752 & 26 & 1.236 & 0.046 & $1.004-1.521$ \\
\hline Low & 1104 & 32 & 1.00 & & \\
\hline School strain & & & & & \\
\hline High & 1807 & 32 & 1.129 & 0.167 & $0.950-1.342$ \\
\hline Low & 2049 & 25 & 1.00 & & \\
\hline
\end{tabular}

the different forms of bullying covered bullying at school, not in other environments. Furthermore, the data for our study were collected in 2010. Since then, the mobile world has evolved greatly, and forms of cyberbullying may also have evolved, and increased. Since adolescents are always one step ahead, there could well be some forms of bullying that our study did not cover. A study by Arnarsson et al. (2019) suggested that cyberbullying might in fact be a separate phenomenon from traditional bullying, since no great overlap existed between these two phenomena within the Nordic countries.

We analysed a wide range of school perceptions, some of which seemed to be associated with being a target of bullying at school. Students who were bullied regularly showed lower engagement with the school and reported poorer student relations. In addition, victims of bullying were more likely to report feelings of loneliness. Problems with peer relations have also been associated with bullying in previous studies 
(see e.g. Pörhölä 2008; Wang et al. 2009; Antoniadou et al. 2019), as have been the negative perceptions of school (see e.g. Mehta et al. 2013).

Interestingly, the current study suggested that students who reported better teacher-student relations were more likely to be bullied at school. As mentioned above, students with more negative perceptions and relationships were in general more likely to be victimised; however, teacher-student relations emerged as the only category in which having more positive relations was associated with being a victim. As noted by Konishi et al. (2010), good teacher-student relations show an association with better performance. Better performance is often seen as teacher adulation and can therefore be one reason to for victimisation (Hamarus 2006). Being 'a teachers' pet' might well be a reason for becoming a target of bullying. Gardella et al. (2019) stated that if students were favoured by teachers, they were more likely victimised. Santinello et al. (2010) found an association between bullying and teacher unfairness was found with students who bullied others but not with victims of bullying. However, as they stated, teachers should provide students with a model of fair treatment.

Although the present study focused on the role of students who were victimised, there is little doubt that teachers can have an important role in interventions to reduce bullying. However, it has been suggested that only a relatively small number of bullying incidents come to the attention of adults (Hamarus 2006). Detection of bullying situations can be difficult for school staff and other adults, since the forms of bullying can be subtle, and the experience of bullying is highly subjective. A study by Haataja et al. (2015) stated that three out of four chronic victims were not recognised by school staff even if there was a structured antibullying program implemented. It is true that Finnish teacher education does address bullying issues, but the present study underlines the need for teachers and school staff to use all possible knowledge and methods they are provided to tackle bullying. In addition, given that teachers spend the most of the school hours with the students, they should not merely intervene in bullying situations, but pay attention to the overall social atmosphere within the school. It is also essential to be aware of the prevailing cultural values, fears, power relations, and norms that reign among student communities (Hamarus and Kaikkonen 2008).

This study has certain limitations. It is important to emphasise that the data used in this study are cross-sectional and that the findings on associations do not determine the causality. The data are also self-reported, hence involving the subjective perceptions of individuals. Moreover, as mentioned above, the perception of being bullied is subjective, with consequent difficulties in defining the concept precisely. It should also be pointed out that certain school-level factors were omitted from the present study. Thus, school size and class size might be factors that could have an influence on perceptions of the school, and of bullying. However, studies have indicated that school perceptions and experiences of bullying do not vary significantly across Finnish schools (see e.g. Luopa et al. 2014; Markkanen et al. 2019). This might be due to the fact that Finland is both socially and culturally a fairly homogeneous country, with the school system offering broadly equal opportunities to receive education. In the PISA (Programme for International Student Assessment) study, Finland has been a top-ranking country in education. In the PISA 2015, the variation between schools was one of the lowest in participating countries. Also the impact of socioeconomic background on student performance in Finland was average OECD country level (Vettenranta et al. 2016). These various factors merit further research. On the other hand, the strengths of the study include nationwide representation and a high response rate. It should also be noted that the questionnaire and the indicators were carefully reviewed and revised by the HBSC research network, and have a good likelihood of capturing valid information on students' school life (Currie et al. 2008; Roberts et al. 2009; :dito_existswww.hbsc.org).

Altogether, this study has the capacity to further raise awareness of bullying, constituting one more step in facing the problem squarely. This study indicates the importance of wider perspectives in understanding bullying in the school context. It reveals some characteristics of the school setting, as well as some individual characteristics, that are associated with bullying. Overall, it appears that improving the entire school experience may well have an effect on the prevalence of victimisation through bullying.

Funding Information Open access funding provided by University of Jyväskylä (JYU).

\section{Compliance with Ethical Standards}

Conflict of Interest The authors declare that they have no conflict of interest.

Open Access This article is distributed under the terms of the Creative Commons Attribution 4.0 International License (http:// creativecommons.org/licenses/by/4.0/), which permits unrestricted use, distribution, and reproduction in any medium, provided you give appropriate credit to the original author(s) and the source, provide a link to the Creative Commons license, and indicate if changes were made.

\section{References}

Acquah, E., Topalli, P.-Z., Wilson, M., Junttila, N., \& Niemi, P. (2016). Adolescent loneliness and social anxiety as predictors of bullying victimisation. International Journal of Adolescence and Youth, 21(3), 320-331. :dito_existshttps://doi.org/10.1080/02673843. 2015.1083449 
Aira, T., Välimaa, R., Paakkari, L., Villberg, J., \& Kannas, L. (2014). Finnish pupils' perceptions of health education as a school subject. Global Health Promotion, 21(3), 6-18. :dito_existshttps://doi.org/ $10.1177 / 1757975914523481$.

Analitis, F., Velderman, M. K., Ravens-Sieberer, U., Detmar, S., Erhart, M., Herdman, M., ... European Kidscreen Group. (2009). Being bullied: associated factors in children and adolescents 8 to 18 years old in 11 European countries. Pediatrics, 123, 569-577. :dito existshttps://doi.org/10.1542/peds.2008-0323

Antoniadou, N., Kokkinos, C. M., \& Fanti, K. A. (2019). Traditional and cyber bullying/victimization among adolescents: examining their psychosocial profile through lantent profile analysis. International Journal of Bullying Prevention. :dito_existshttps://doi.org/10.1007/ s42380-019-00010-0.

Arnarsson, A., Nygren, J., Nyholm, M., Torsheim, T., Augustine, L., Bjereld, Y., Markkanen, I., Schnohr, C. W., Rasmussen, M., Nielsen, L., \& Bendsen, B. (2019). Cyberbullying and traditional bullying among nordic adolescents and their impact on life satisfaction. Scandinavian Journal of Public Health. :dito existshttps://doi. org/10.1177/1403494818817411.

Callaghan, M., Kelly, C., \& Molco, M. (2014). Exploring traditional and cyberbullying among Irish adolescents. International Journal of Public Health, 60, 199-206. :dito_existshttps://doi.org/10.1007/ s00038-014-0638-7.

Chester, K. L., Callaghan, M., Cosma, A., Donnelly, P., Craig, W., Walsh, S., \& Molcho, M. (2015). Cross-national time trends in bullying victimization in 33 countries among children aged 11, 13 and 15 from 2002 to 2010. The European Journal of Public Health, 25(2), 61-64. :dito_existshttps://doi.org/10.1093/eurpub/ckv029.

Craig, W., Harel-Fisch, Y., Fogel-Grinvald, H., Dostaler, S., Heland, J., Simons-Morton, B., ... HBSC Bullying Writing Group. (2009). A cross-national profile of bullying and victimization among adolescents in 40 countries. International Journal of Public Health, 54(2), 216-224. :dito_existshttps://doi.org/10.1007/s00038-009-5413-9.

Currie, C., Nic Gabhainn, S., Godeau, E., Roberts, C., Smith, R., Currie, D., et al. (Eds.). (2008). Inequalities in young people's health: HBSC international report from the 2005/2006 survey. Copenhagen: World Health Organization, Retrieved from WHO :dito_existshttp://www. euro.who.int/ data/assets/pdf file/0005/53852/E91416.pdf. Accessed 22 Oct 2019.

Currie, C., Zanotti, C., Morgan, A., Currie, D., de Looze, M., Roberts, C., ... Barnekow, V. (Eds.). (2012). Social determinants of health and well-being among young people. Health Behaviour in School-aged Children (HBSC) study: international report from the 2009/2010 survey. Copenhagen, WHO Regional Office for Europe. Retrieved from WHO: :dito_existshttp://www.euro.who.int/_data/assets/pdf file/0003/163857/Social-determinants-of-health-and-well-beingamong-young-people.pdf?ua=1. Accessed 22 Oct 2019.

Due, P., Holstein, B. E., Lynch, J., Diderichsen, F., Gabhain, S. N., Scheidt, P., ... HBSC Bullying Writing Group. (2005). Bullying and symptoms among school-aged children: international comparative cross sectional study in 28 countries. The European Journal of Public Health, 15, 128-132. :dito_existshttps://doi.org/10.1093/ eurpub/cki105

Due, P., Holstein, B. E., \& Soc, M. S. (2008). Bullying victimization among 13 to 15 -year-old school children: results from two comparative studies in 66 countries and regions. International Journal of Adolescent Medicine and Health, 20(2), 209-221. :dito existshttps://doi.org/10.1515/IJAMH.2008.20.2.209.

Due, P., Merlo, J., Harel-Fisch, Y., Damsgaard, M. T., Holstein, B. E., Hetland, J., Currie, C., ... Lynch, J. (2009). Socioeconomic inequality in exposure to bullying during adolescence: a comparative, crosssectional, multilevel study in 35 countries. American journal of public health, 99(5), 907-914. :dito existshttps://doi.org/10.2105/ AJPH.2008.139303.
Due, P., Damsgaard, M., Rasmussen, M., \& Holstein, B. (2019). Trends in social inequality in exposure to bullying at school 1994-2018. Journal of Education, Society and Behavioural Science, 32(1), 1-7. :dito_existshttps://doi.org/10.9734/jesbs/2019/v32i130160.

Erginoz, E., Alikasifoglu, M., Ercan, O., Uysal, O., Alp, Z., Ocak, S., ... Albayrak Kaymak, D. (2015). The role of parental, school, and peer factors in adolescent bullying involvement: results from the Turkish HBSC 2005/2006 Study. Asia-Pacific Journal of Public Health, 27, 1591-1603.:dito_existshttps://doi.org/10.1177/ 1010539512473144.

Finnish National Board of Education. (2016). National Core Curriculum For Basic Education 2014. Publications 2016:5. Helsinki, Finnish National Board of Education.

Freeman, J. G., Samdal, O., Klinger, D. A., Dur, W., Griebler, R., Currie, D., \& Rasmussen, M. (2009). The relationship of schools to emotional health and bullying. International Journal of Public Health, 54(2), 251-259. :dito_existshttps://doi.org/10.1007/s00038-009$5421-9$.

Gardella, J. H., Fisher, B. W., Teurbe-Tolon, A. R., et al. (2019). Students' reasons for why they were targeted for in-school victimization and bullying. International Journal of Bullying Prevention. :dito existshttps://doi.org/10.1007/s42380-019-00017-7.

Gendron, B. P., Williams, K. R., \& Guerra, N. G. (2011). An analysis of bullying among students within schools: estimating the effects of individual normative beliefs, self-esteem, and school climate. Journal of School Violence, 10, 150-164. :dito_existshttps://doi. org/10.1080/15388220.2010.539166.

Glew, G. M., Fan, M., Katon, W., \& Rivara, F. P. (2008). Bullying and school safety. The Journal of Pediatrics, 152, 123-128. :dito existshttps://doi.org/10.1016/j.jpeds.2007.05.045.

Haapasalo, I., Välimaa, R., \& Kannas, L. (2010). How comprehensive school students perceive their psychosocial school environment. Scandinavian Journal of Educational Research, 54, 133-150. :dito_existshttps://doi.org/10.1080/00313831003637915.

Haapasalo, I., Välimaa, R., \& Kannas, L. (2012). Associations between Finnish 9th grade students' school perceptions, health behaviors, and family factors. Health Education, 112, 256-271. :dito existshttps://doi.org/10.1108/09654281211217786.

Haataja, A. (2016). Implementing the KiVa antibullying problem: what does it take? Turku: University of Turku Retrieved from: :dito existshttp://urn.fi/URN:ISBN:978-951-29-6553-3. Accessed $\overline{7}$ Nov 2019.

Haataja, A., Sainio, M., Turtonen, M., \& Salmivalli, C. (2015). Implementing the KiVa antibullying program: recognition of victimized students. Educational Psychology, 36, 595-611. :dito existshttps://doi.org/10.1080/01443410.2015.1066758.

Hager, A. D., \& Leadbeater, B. J. (2015). The longitudinal effects of peer vitimization on physical health from -adolescence to young adulthood. Journal of Adolescent Health, 58(3), 330-336. :dito_ existshttps://doi.org/10.1016/j.jadohealth.2015.10.014.

Hamarus, P. (2006). Koulukiusaaminen ilmiönä. Yläkoulun oppilaiden kokemuksia kiusaamisesta. [School bullying as a phenomenon. Some experiences of Finnish lower secondary school pupils]. Jyväskylä: University of Jyväskylä.

Hamarus, P., \& Kaikkonen, P. (2008). School bullying as a creator of pupil peer pressure. Educational Research, 50, 333-345. :dito existshttps://doi.org/10.1080/00131880802499779.

Harel-Fisch, Y., Walsh, S.D., Fogel-Grinvald, H., Amitai, G., Pickett, W., Molcho, M., .... Members of the HBSC Violence and Injury Prevention Focus Group. (2011). Negative school perceptions and involvement in school bullying: a universal relationship across 40 countries. Journal of Adolescence, 34, 639-652. :dito existshttps:// doi.org/10.1016/j.adolescence.2010.09.008

Hong, J. S., \& Espelage, D. L. (2012). A review of research on bullying and peer victimization in school: an ecological system analysis. 
Aggression and Violent Behavior, 17(4), 311-322. :dito_ existshttps://doi.org/10.1016/j.avb.2012.03.003.

Juvonen, J., Wang, Y., \& Espinoza, G. (2010). Bullying experiences and compromised academic performance across middle school grades. The Journal of Early Adolescence, 31(1), 152-173. :dito existshttps://doi.org/10.1177/0272431610379415.

Konishi, C., Hymel, S., Zumbo, B. D., \& Li, Z. (2010). Do school bullying and student-teacher relationships matter for academic achievement? A multilevel analysis. Canadian Journal of School Psychology, 25(1), 19-39. :dito existshttps://doi.org/10.1177/ 0829573509357550.

Luopa, P., Paananen, R., Kivimäki, H., Matikka, A., Vilkki, S., Jokela, J., Laukkarinen, E., \& Paananen, R. (2014). Nuorten hyvinvointi Suomessa 2000-2013: kouluterveyskyselyn tulokset. [Adolescents' well-being in finland: results of the School Health Promotion Study 2000-2013.]. Helsinki: National Institute for Health and Welfare.

Markkanen, I., Välimaa, R., \& Kannas, L. (2019). Associations between students' perceptions of the psychosocial school environment and indicators of subjective health in Finnish comprehensive schools. Children \& Society, 33, 488-502. :dito_existshttps://doi.org/10. $1111 /$ chso. 12334

Mehta, S. B., Cornell, D., Fan, X., \& Gregory, A. (2013). Bullying climate and school engagement in ninth-grade students. Journal of School Health, 83(1), 45-52. :dito_existshttps://doi.org/10.1111/j. 1746-1561.2012.00746.x.

Minkkinen, J. (2015). The structural model of child well-being, children's emotional well-being and social relationships in elementary school. Acta Universitatis Tamperensis 2063. Tampere: Tampere University Press.

Molcho, M., Craig, W., Due, P., Pickett, W., Harel-Fisch, Y., Overpeck, M., \& HBSC Bullying Writing Group. (2009). Cross-national time trends in bullying behaviour 1994-2006: findings from Europe and North America. International Journal of Public Health, 54(2), 225 234. :dito existshttps://doi.org/10.1007/s00038-009-5414-8.

Nansel, T. R., Craig, W., Overpeck, M. D., Saluja, G., \& Ruan, W. J. (2004). Cross-national consistency in the relationship between bullying behaviors and psychosocial adjustment. Archives of Pediatrics and Adolescent Medicine Journal, 158, 730. :dito_existshttps://doi. org/10.1001/archpedi.158.8.730.

Olweus, D. (1993). Bullying at school: what we know and what we can do. Cambridge: Blackwell Publishers.

Paakkari, O., \& Pakkari, L. (2019). Health literacy and the school curriculum: the example of Finland. In U. Bauer, O. Orkan, P. Pinheiro, D. Levin-Zamir, \& K. Sorensen (Eds.), International handbook of health literacy - research, practice, and policy across the lifespan (pp. 521-534). Bristol: Policy Press.

Patchin, J. W., \& Hinduja, S. (2012). Cyberbullying: an update and synthesis of the research. In J. W. Patchin \& S. Hinduja (Eds.), Cyberbullying, prevention and response. Expert Perspectives (p. 13). New York: Routledge.

Pavri, S. (2015). Loneliness: the cause or consequence of peer victimization in children and youth. The Open Psychology Journal, 8, 78-84. :dito_existshttps://doi.org/10.2174/1874350101508010078.

Pörhölä, M. (2008). Koulukiusaaminen nuoren hyvinvointia uhkaavana tekijänä - miten käy kiusatun ja kiusaajan vertaissuhteille? [School bullying as a threat to young people's well-being - what happens to the peer relationships of the bullied and the bullies?]. In M. Aaltonen, K. Eräkallio \& S. Myllyniemi (Eds.) Polarisoituva nuoruus? Nuorten elinolot -vuosikirja 2008 [Polarized youth? Young people's living conditions yearbook 2008]. pp. 94-104. Youth Research Network \& Stakes. Retrieved from: :dito existshttp://www.nuorisotutkimusseura.fi/images/julkaisuja/ polarisoituvanuoruus.pdf. Accessed 22 Oct 2019.
Roberts, C., Freeman, J., Samdal, O., Schnohr, C. W., de Looze, M. E., Nic Gabhainn, S., et al. (2009). The Health Behaviour in Schoolaged Children (HBSC) study: methodological developments and current tensions. International Journal of Public Health, 54(2), 140-150. :dito_existshttps://doi.org/10.1007/s00038-009-5405-9.

Sainio, M. (2014). KiVa Koulu® -ohjelma suomalaisissa peruskouluissa: Miten ohjelmaa toteutetaan tai miksi sitä ei käytetä? [KiVa program in Finnish comprehensive schools: how the program is implemented or why it is not in use?]. A report funded by the Ministry of Education and Culture. Retrieved from KiVa Koulu: :dito existshttp://www.kivakoulu.fi/assets/files/KiVa-tutkimusraportti. pdf.

Salmivalli, C. (2010). Bullying and the peer group: a review. Aggression and Violent Behavior, 15(2), 112-120. :dito_existshttps://doi.org/10. 1016/j.avb.2009.08.007.

Sanders, C. E. (2019). Breakfast skipping, psychological distress, and involvement in bullying: is there a connection? International Journal of Bullying Prevention. :dito_existshttps://doi.org/10.1007/ s42380-019-00008-8.

Santinello, M., Vieno, A., \& De Vogli, R. (2010). Bullying in Italian schools: the role of perceived teacher unfairness. European Journal of Psychology of Education, 26, 235-246 Retrieved from :dito existshttp://www.jstor.org/stable/23883607.

Tippett, N., \& Wolke, D. (2014). Socioeconomic status and bullying: a meta-analysis. American Journal of Public Health, 104(6), e48-e59. :dito_existshttps://doi.org/10.2105/AJPH.2014.301960.

Turner, I., Reynolds, K. J., Lee, E., Subasic, E., \& Bromhead, D. (2014). Well-being, school climate, and the social identity process: a latent growth model study of bullying perpetration and peer victimization. School Psychology Quarterly, 29, 320-335. :dito_existshttps://doi. org/10.1037/spq0000074.

UNESCO. (2019). Behind the numbers: ending school violence and bullying. Paris: UNESCO. Retriewed from UNESCO :dito existshttps://unesdoc.unesco.org/ark:/48223/pf0000366483? posInSet=1\&queryId=N-EXPLORE-cd7db641-398b-4338-b588$81 \mathrm{e} 8 \mathrm{f} 64 \mathrm{~d} 9240$.

Välimaa, R., Kannas, L., Lahtinen, E., Peltonen, H., Tynjälä, J., \& Villberg, J. (2008). Innovative health education curriculum and other investments for promoting mental health and social cohesion among children and young people. In Social cohesion for mental well-being among adolescents. Copenhagen: WHO Regional Office for Europe.

Vettenranta, J., Välijärvi, J., Ahonen, A., Hautamäki, J., Hiltunen, J., Leino, K., Lähteinen, S., Nissinen, K., Nissinen, V., Puhakka, E., Rautopuro, J., \& Vainikainen, M.-P. (2016). PISA 2015: Huipulla pudotuksesta huolimatta. [PISA 2015: still at the top despite the drop]. Publications of The Ministry on Ecducation and Culture 2016:41. Retreived from Ministry of Eduation and culture: :dito existshttp://julkaisut.valtioneuvosto.fi/bitstream/handle/10024/ 79052/okm41.pdf. Accessed 7 Nov 2019.

Wang, J., Iannotti, R. J., \& Nansel, T. R. (2009). School bullying among adolescents in the United States: physical, verbal, relational, and cyber. Journal of Adolescent Health, 45, 368-375. :dito_ existshttps://doi.org/10.1016/j.jadohealth.2009.03.021.

Yang, C., Sharkey, J. D., Reed, L. A., Chen, C., \& Dowdy, E. (2018). Bullying victimization and student engagement in elementary, middle ans high schools: moderating role of school climate. School Psychology Quaterly, 33(1), 53-64. :dito_existshttps://doi.org/10. 1037/spq0000250.

Zych, I., Ortega-Ruiz, R., \& del Rey, R. (2015). Systematic review of theoretical studies on bullying and cyberbullying: facts, knowledge, prevention, and intervention. Aggression and Violent Behavior, 23, 1-21. :dito_existshttps://doi.org/10.1016/j.avb.2015.10.001. 